\title{
USDA PANEL EVALUATES CATILE VACCINE TEST
}

WASHINGTON, D.C.-The Agri- $\mid$ and whether the chartering activities cultural Biotechnology Research Advisory Committee (ABRAC), still negotiating its proper mandate, also for the first time tackled a far more concrete issue during its meeting early in January at U.S. Department of Agriculture (USDA) headquarters. The committee evaluated and approved a request from researchers at Texas A \& M University (College Station, TX) to test in cattle a new vaccine to prevent brucellosis, a devastating disease that causes abortions in animals and can cause undulant fever in man. The committee's recommendation will be forwarded to regulatory officials within the Animal and Plant Health Inspection Service (APHIS) at USDA. Officials at the Centers for Disease Control (CDC, Atlanta, GA) also must evaluate the proposal

The ABRAC action holds both substantive and symbolic significance. Committee members have been pondering charter documents for many months (Bio/Technology 6:1274, Nov. '88). The drawn-out process has left them, USDA officials, and outsiders champing at the bit, wondering when \section{would cease. For example, at the out-} set of the January meeting, the normally placid USDA Assistant Secretary for Science and Education Orville Bentley urged the committee to "finalize the guidelines." Although "you can't answer every question," he said, "there is an urgency to get this job done." The committee fell short of that goal, but expects to publish draft guidelines and a manual for conducting field tests soon after its next meeting, scheduled for March 22-23, 1989.

Meanwhile, the committee squarely faced another urgent issue-namely, research to control brucellosis. APHIS now spends about $\$ 50$ million annually in eradication and surveillance programs for this disease, which afflicts cattle herds in several southern states and other parts of the world.

Recently several research groups, veterinarian Garry Adams, have developed experimental vaccines using alternative technologies. The Texas research group used transposonincluding one led by Texas A \& M based mutagenesis to inactivate normal outer-membrane lipopolysaccharide synthesis in $B$. abortus. The resulting mutant bacterium no longer causes disease in mice or goats. And so far it does not revert to its original pathogenic state, Adams says.

To begin testing the product, Adams and his colleagues inoculated cattle with a killed version of the bacterial vaccine early in 1988 . Because the B. abortus pathogen and other experimental vaccines behave very differently in mice and goats than in cattle, the latter must be used to evaluate vaccines. To get statistically valid results, at least 25 animals are needed in each of the four test groups in the current study.

Although ABRAC approached the Texas A \& M proposal with some uncertainty about the committee's role in conducting such a review, committee members soon overcame that reluctance. The committee unanimously approved the amended Texas A \& $\mathrm{M}$ proposal-taking a step that some members say should enhance ABRAC's "credibility."

-Jeffrey L. Fox

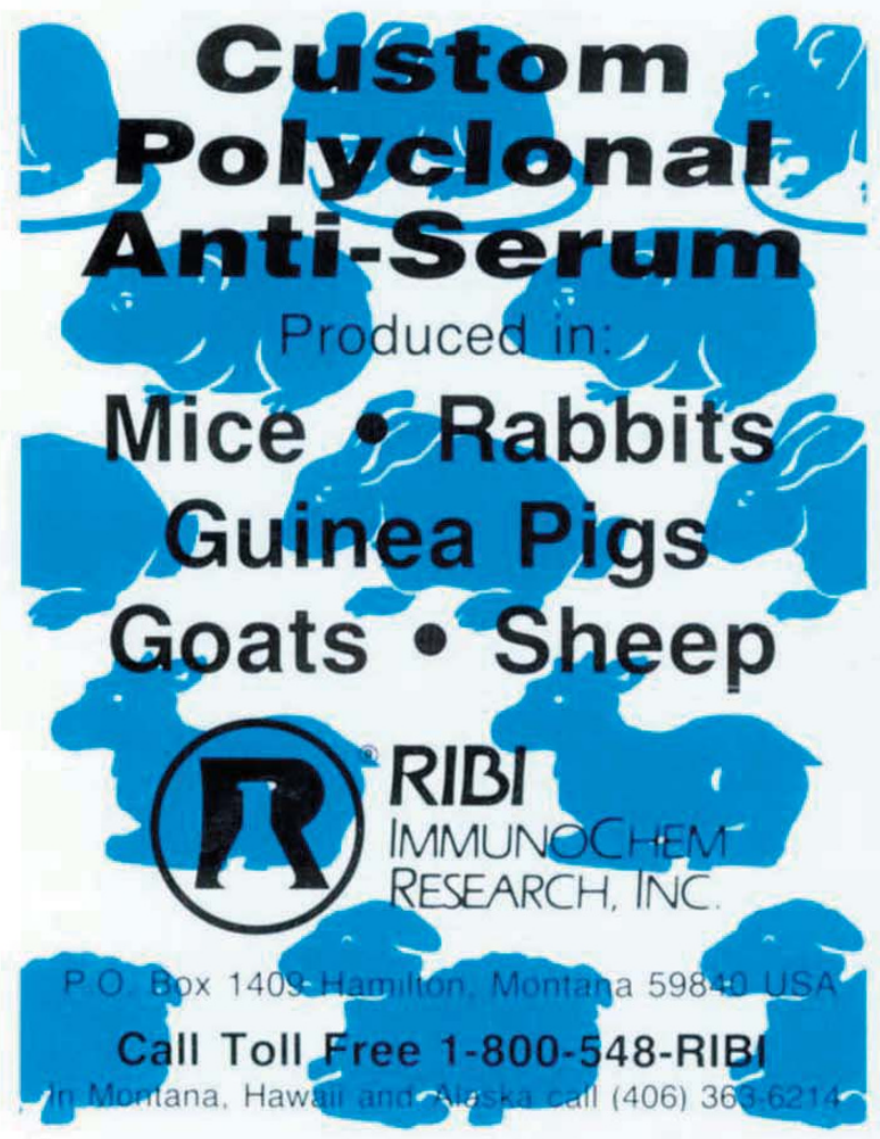

Write in No. 4 on Reader Service Card
Because they couple directly to culture vessels from above, Bellco Overhead Drives are ideal for largevessel or high-viscosity stirring. They also eliminate motors beneath cultures and allow easy connection of fluid lines. Two models offer a wide choice of vessel sizes, paddle impellers and perfusion wand assemblies for any stirring need. \section{Create a Stir}
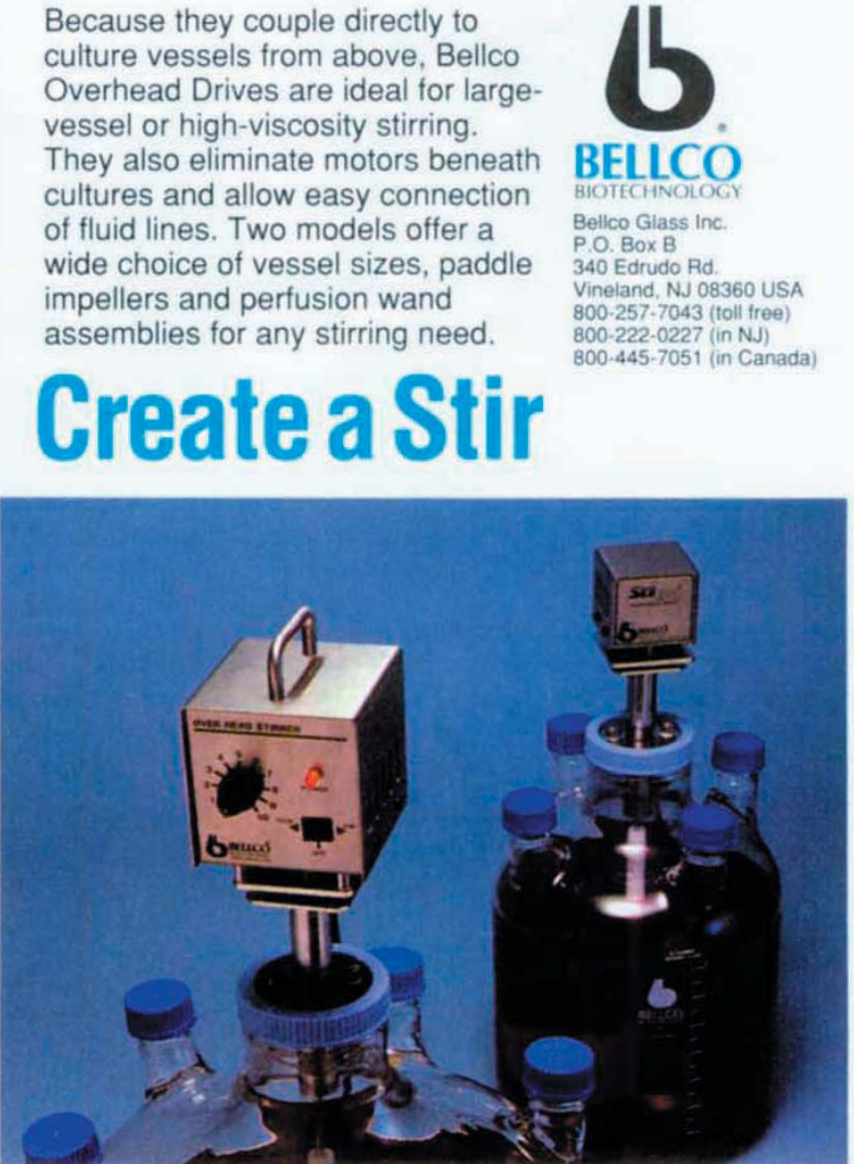

Write in No. 28 on Reader Service Card

BIO/TECHNOLOGY VOL. 7 FEBRUARY 1989 